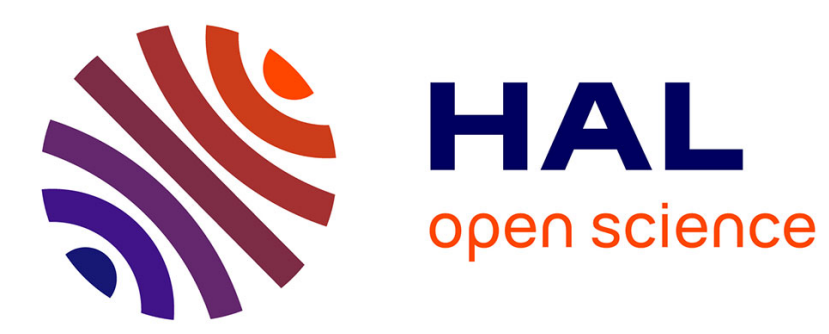

\title{
First occurrence of Ibacinae (Eucrustacea: Decapoda: Scyllaridae) from the Eocene of Pakistan
}

Denis Audo

\section{To cite this version:}

Denis Audo. First occurrence of Ibacinae (Eucrustacea: Decapoda: Scyllaridae) from the Eocene of Pakistan. Journal of Systematic Palaeontology, 2019, 17 (6), pp.533-538. 10.1080/14772019.2017.1405085 . hal-02274560

\section{HAL Id: hal-02274560 \\ https://hal.sorbonne-universite.fr/hal-02274560}

Submitted on 30 Aug 2019

HAL is a multi-disciplinary open access archive for the deposit and dissemination of scientific research documents, whether they are published or not. The documents may come from teaching and research institutions in France or abroad, or from public or private research centers.
L'archive ouverte pluridisciplinaire HAL, est destinée au dépôt et à la diffusion de documents scientifiques de niveau recherche, publiés ou non, émanant des établissements d'enseignement et de recherche français ou étrangers, des laboratoires publics ou privés. 
First occurrence of Ibacinae (Eucrustacea: Decapoda: Scyllaridae) from the Eocene of Pakistan

Denis Audo ${ }^{\mathrm{a}, \mathrm{b}}$

aUMR CNRS 6118 Géosciences, Université de Rennes I, Campus de Beaulieu, avenue du général Leclerc, 35042 Rennes cedex, France. E-mail: denis.audo@edu.mnhn.fr

b'Muséum national d'Histoire naturelle, Centre de Recherche sur la Paléobiodiversité et les Paléoenvironnements (CR2P, UMR 7207), Sorbonne Universités, MNHN, UPMC, CNRS, 57 rue Cuvier F-75005 Paris, France. 


\begin{abstract}
The fossil record of slipper lobsters (Scyllaridae) is very poor, even though the earliest species of the modern slipper lobsters (Neoscyllaridae) are known from the Early Cretaceous. Among the clades "subfamilies" of slipper lobsters, perhaps the most remarkable is Ibacinae (currently monogeneric), which contains species with a very wide carapace (cephalothoracic shield) and very deep incisions. Fossil species assigned to Ibacinae were reported from the Oligocene and Pleistocene. However, a recent reappraisal of Scyllaridae phylogeny revealed that the genus to which these two fossil occurrences belong is not closely allied to Ibacinae. Therefore Ibacinae was left with no known fossil record until the present study. The present study describes a new species which can be confidently assigned to Ibacinae (closely allied to Ibacus) from the Ypresian (early Eocene) from the Ghazij formation in Shaisuro, Dera Ghazi Khan District, Pakistan. This new species, ?Ibacus mazariorum corresponds to the oldest recorded occurrence of Ibacinae. The Ghazij formation was deposited on the north-western margin of the India-Pakistan plate during a critical period, shortly before the collision between of the India-Pakistan plate with Asia. Consequently, it is possible that Ibacus, and closely allied species may have remained in the same biogeographic area since Eocene. Considering the extant and fossil distribution of Ibacinae, additional fossil discoveries may be found in existing collections and fossiliferous outcrops from Neotethys, Indian and Pacific oceans.
\end{abstract}

Keywords: Achelata; Ibacus; Ypresian; Ghazij formation; distribution range; Neotethys.

\title{
Introduction
}

Slipper lobsters (Scyllaridae) are easy to recognize decapod crustaceans: contrary to almost all other crustaceans, their antennae do not have a long flagellum, but a rather short flagellum formed of a few podomeres (Holthuis 1991; Lavalli \& Spanier 2012; Haug et al. 2016). Besides, in the case of modern species, (Neoscyllarida Haug, Audo, Charbonnier, Palero, Petit, Abi Saad \& Haug, 2016: a clade recently erected to distinguish modern slipper lobsters and their closest fossil relatives), the antenna is even more peculiar: very wide, flattened, and asymmetrical. These antennae resemble a shovel, hence, Scyllaridae are sometimes called 
"shovel-nosed lobster". However, contrary to what this name implies, antennae are probably not used in burying, but rather to protect antennulae, to steer the animal during swimming and to flip upside-down opponents during antagonistic behaviour (Spanier \& Weihs 1992; Lavalli et al. 2007).

Scyllaridae have a quite poor fossil record compared to other decapod crustaceans (Audo \& Charbonnier 2012). Their known fossil diversity is rather low, discontinuous stratigraphically and geographically (see supplementary material table 1).

Based upon the available fossil evidence, we know that slipper lobsters have diverged from other achelates as early as the Late Jurassic (Haug et al. 2009). Witnesses of the evolution of slipper lobsters (with a mosaic of primitive and derived characters) are discovered as late as Late Cretaceous (Haug et al. 2016; Charbonnier et al. 2017), but the diversification of Neoscyllaridae occurred earlier, no later than the Early Cretaceous (see supplementary material table 1). This diversification gave rise to at least five clades (see phylogenetic tree in Yang et al. 2012). Four of these clades correspond to the subfamilies defined by Holthuis (1985): Arctidinae Holthuis, 1985, Scyllarinae Latreille, 1825, Theninae Holthuis, 1985 and Ibacinae Holthuis, 1985. The fifth clade is formed by Evibacus Smith, $1869+$ Parribacus Dana, 1852, formerly assigned to Ibacinae (Holthuis 1985), but which are more closely related to Scyllarinae and Theninae than to Ibacus Leach, 1815 (Yang et al. 2012). Among these aforementioned clades or "subfamilies", at least three are known in the fossil record (supplementary material table 1): (1) Arctidinae and (2) Scyllarinae which supposedly first occur in Early Cretaceous; (3) the unnamed clade containing Parribacus and Evibacus, which is represented in the fossil record by two species of Parribacus in Oligocene (Glaessner 1965) and Pleistocene (Hu \& Tao 1996), both previously assigned to Ibacinae. Theninae has not yet been identified in the fossil record. With the exclusion of Parribacus from Ibacinae, it appears that no true Ibacinae was discovered in the fossil record before the present study. This situation is slightly surprising as Ibacinae could have been easily identified since it contains the most remarkable species, with the widest and most flattened (in proportion) carapaces (cephalothoracic shields).

The present study investigates a fossil from the Ypresian of Pakistan, which displays characters typical of Ibacinae, closely matching those of Ibacus, and assesses its significance: this discovery improves our knowledge of Scyllaridae fossil diversity and of the minimum age of Ibacinae. 


\section{Geological context}

The studied specimen was collected from the Ghazij formation in Shaisuro (Fig. 1), $150 \mathrm{~km}$ south-west of Dera Ghazi Khan, Punjab Province (Collins \& Morris 1978). The Ghazij formation crops out over several hundreds of kilometres near the suture zone between IndiaPakistan plate and Asia (Clyde et al. 2003). This formation has an interesting origin: it was deposited on the north-western margin of the India-Pakistan plate about 50-56 MA ago (Ypresian, early Eocene), at a time when India-Pakistan plate was just beginning its collision with Asia (Clementz et al. 2011; note that the timing of this collision is still poorly constrained: Zhu et al. 2005). This important collision is probably recorded by the formation. Indeed, the formation was initially deposited under marine conditions, then in paralic conditions and the sedimentation at the top of the formation is of terrestrial origin (Clyde et al. 2003). In this context, it is very likely that this variation in the sedimentation is a direct result of the collision between India-Pakistan plate and Asia and of the uplifting of the Ghazij formation.

Surprisingly, the specimen described herein was labelled as coming from the "top of the Ghazij shales, Shaisuro" (handwritten on the label placed with the specimen), and the locality is referred by Collins \& Morris (1978: p. 961) as “top of the Ghazij formation”. As explained in Clyde et al. (2003), the Ghazij formation ends up with sedimentation of terrestrial origin, so a marine slipper lobster is unlikely to come from the upper most part of the Ghazij formation. Rather, it may come from the top of the green shales, in the lower part of the Ghazij formation. The shales mentioned on the label may represent the uppermost part of the Ghazij formation in Shaisuro (opposed to the top of the whole Ghazij formation), which may explain the confusion. Unfortunately, no information is available on the precise horizon of the Ghazij formation from which this specimen comes from. No information can be gathered from the specimen itself either, as it is preserved in a nodule, and the surrounding sediment was removed.

The Ypresian of Shaisuro has also yielded 6 specimens of the brachyuran Glyphithyreus wetherelli (Bell, 1858) (Collins \& Morris 1978). In addition, three other brachyuran species are reported from Ghazij formation in other outcrops, Laeviranina sinuosa Collins \& Morris, 1978, Pyromaia inflata Collins \& Morris, 1978, Pakicarcinus orientalis (Collins \& Morris, 1978) (Collins \& Morris 1978; Charbonnier et al. 2013). 


\section{Material and Methods}

This study is based on the sample NHMUK In.48229 housed in the palaeontological collections of the Natural History Museum, London, United Kingdom (NHMUK). This specimen was collected by Ernest Sheppard Pinfold F.G.S., who was a geologist of the Attock Oil Company (Claire Mellish, pers. comm. 2017). The fossil is preserved in three dimensions within a concretion and was probably only minimally flattened during diagenesis.

The specimen was imaged in cross-polarized light (Bengtson 2000; Haug et al. 2011) and with image stacking to enhance the contrast and ensure the whole specimen is in focus. In addition, the dorsal aspect of the specimen was imaged at two slightly diverging angles to produce stereo pairs with an exaggerated stereographic effect (Fig. 2A).

The morphological terminology follows that used by Holthuis (1985), except that the term "ridge” is replaced by “carina”.

Abbreviations: $\mathrm{CL}=$ Carapace Length, measured from the posterior margin of ocular incision to the posterior margin (parallel to median line); $\mathrm{CW}=$ Carapace width, measured as the maximum width, perpendicular to median line.

\section{Systematic palaeontology}

“Class” Malacostraca Latreille, 1802

“Order” Decapoda Latreille, 1802

“Suborder” Pleocyemata Burkenroad, 1963

Achelata Scholtz and Richter, 1995

“Family” Scyllaridae Latreille, 1825

Neoscyllarida Haug, Audo, Charbonnier, Palero, Petit, Abi Saad and Haug, 2016

“Subfamily” Ibacinae Holthuis, 1985

“Genus” ?Ibacus Leach, 1815

Type Species. — Ibacus perroni Leach, 1815, by monotypy. 
Original diagnosis (Leach 1815). — Shell broader than long, subdepressed, on each side very deeply fissured; eyes inserted at the anterior margin; peduncle thick, recurved, acuminated towards its extremity. External pedipalpes with the two first joints externally crested; second joint internally, with many fissures; flagrum tripartite; the last segment manyjointed. Legs ten, short; two anterior pair abruptly thicker than the others; fifth pair pair didactyle; thumb short. Tail with five membranaceous lamellæ, which are crustaceous at their base. Interior antennce three-jointed, terminated by two many-jointed setæ: external antennce squamiform, four-jointed. [sic]

Emended diagnosis (Holthuis 1985: rearranged from key to genera). - Exopods of all maxillipeds with a multi-articulate flagellum; Carapace strongly depressed, with a deep cervical incision in the lateral margin. Mandible with a simple or two-segmented palp ("subfamily" Ibacinae); orbits anteriorly open, placed on the anterior margin of the carapace. Cervical incision usually open, at least at the base. Carapace without posteromedian tooth. Atlantic and Indo-West Pacific; Dorsal surface of the body smooth and punctate, not tuberculate, sometimes pubescent. Carapace with postrostral and branchial carinae distinct. Distance between the orbits as long as or shorter than the distance separating each orbit from the nearest anterolateral angle. Fifth abdominal somite with posteromedian spine. Mandibular palp consisting of a single segment. (Note that the key originally included biogeographic characters which are herein preserved).

?Ibacus mazariorum nov. sp.

Fig. 2

Diagnosis. - Carapace (cephalothoracic shield) dorsoventrally flattened; narrow concave frontal margin framed by a pair of spines; U-shaped ocular incisions, with converging axis, opening on the anterior margin; short postorbital and long branchial carinae aligned; anterior submedian carina present.

\section{Description (Figs 2B, 2D).}

Outline of carapace. - Carapace (cephalothoracic shield) dorsoventrally flattened, subovate in outline in dorsal aspect $(\mathrm{CL}=c a 20.4 \mathrm{~mm}, \mathrm{CW}=c a 36.1 \mathrm{~mm}$; lateral margin poorly preserved); narrow concave frontal margin framed by a pair of spines; ocular incision 
U-shaped, opening on the anterior margin, orientated slightly obliquely, their axis converging anteriorly; lateral margin eroded; cervical incision indistinct if present, possibly reaching a small tubercle (intercervical carina?); postcervical incision, if any, not visible; posterior margin poorly preserved, straight between branchial carina and median line.

Carapace grooves and carina. - cervical groove indistinct, separating the short postorbital carina from the long branchial carina, not cutting median carina (no separation between postrostral carina and posterior postrostral carina); branchiocardiac groove shallow, extending longitudinally along the median carina; postcervical groove shallow, joined to branchiocardiac groove, probably cutting median carina (isolating posteriorly the intestinal carina); postrostral and posterior postrostral carinae merged into a single median carina extending on the posterior $2 / 3$ of the carapace, forming four long crests, first three successively longer, last crest shorter; short intestinal carina intercalated between median carina and posterior margin; thin and raised orbital carina surrounding ocular incision; short, raised postorbital carina, about $1 / 8$ as long as branchial carina; tubercle slightly posterior and outward of postorbital carina, possibly representing a short intercervical carina; long, straight and raised branchial carina, extending parallel to median line to the posterior margin; raised anterior submedian carina, slightly longer than postorbital carina, subdivided into two crests, lying subparallel to median line, at equal distance from postorbital and median carinae; raised posterior carina, parallel to posterior margin, not preserved medially.

Carapace ornamentation. - carapace smooth medially, visibily ornamented laterally with pits, which may correspond to the erosion of tubercles (see Charbonnier et al. 2014: 333, for typical example of variations due to the preservation).

Etymology. - dedicated to the Mazari tribe, which inhabits the area where the fossil was discovered.

Type Material. - Holotype NHMUK In.48229, by monotypy (Fig. 2).

Geographic and Stratigraphic Range. - Ghazij formation, Shaisuro, Mazari tribal area, ca 150 km south-west of Dera Ghazi Khan, Punjab Province, 28²7’ N., 69 50’ E. Ypresian stage, Eocene (locality 3 in Collins \& Morris 1978).

Discussion. - ?Ibacus mazariorum nov. sp. is ascribed to Neoscyllarida based upon its wide, dorsoventrally flattened carapace with marked branchial and median carina and large ocular incisions placed on the anterior margin. Similar disposition, with a large carapace can also be 
found in polychelidan lobsters, brachyurans and stomatopods. However, the disposition of carina and grooves in these taxa is completely different, notably, because they do not possess any anterior submedian carina, neither have a branchial groove extending along the median carina as much as in ?Ibacus mazariorum nov. sp. As a whole, the whole pattern of grooves and carinae on the carapace is only compatible with some genera of slipper lobsters (Scyllaridae). Within Scyllaridae, such a wide carapace is only documented in the Neoscyllarida, other groups having more elongated carapaces. More precisely, the ocular incisions (or orbits) which open anteriorly, are nearer to each other than to the anterolateral angle, the raised branchial and postrostral carinae are diagnostic of Ibacus Leach, 1815 (Holthuis 1985). However, due to the fragmentary condition of this fossil, it is not possible to verify if this species has the typical deep cervical incision of Ibacus. It is therefore more reasonable to assign this species with some doubts to Ibacus. ?Ibacus mazariorum is the only known fossil species with distinct affinities with Ibacus. It is easily distinguished from all other species of Ibacus by its particularly narrow frontal margin, narrower than the ocular incision width, wider in all other species.

\section{Discussion}

\section{Minimum age of Ibacinae}

?Ibacus mazariorum is the only known occurrence of a representative of Ibacinae. This occurrence proves that Ibacinae already diverged from their nearest Scyllaridae relatives before the early Eocene. This new data may help calibrate the divergence time between the “subfamilies” of Scyllaridae for future works similar to that proposed by Palero et al. (2009).

\section{Distribution range of Ibacinae and Ibacus in past and extant environments}

?Ibacus mazariorum is either a representative of Ibacus or a very close relative to this genus. The distribution range of Ibacus is currently limited to the Indian ocean and West-Pacific (Holthuis 1985, Holthuis 1991). ?Ibacus mazariorum used to live on the north-western margin of India-Pakistan plate, in the Neotethys ocean. Its distribution matches that of extant species of Ibacus. It is undoubtedly a case of phylogenetic conservatism of the distribution range. However, with only one specimen in one locality, it is not possible to know if the size of the distribution range varied for Ibacus and its closest relatives.

As a result, we may have better chances to complete our poor knowledge of fossil Ibacinae by investigating existing collections and fossiliferous outcrops from Mediterranean Sea, 
Neotethys, Indian and Pacific oceans. Besides, at the time, the nearby Mediterranean part of Neotethys was still connected to the Eastern Neotethys (Golonka 2002). Therefore, it is surprising that Ibacinae does not occur in present-day Mediterranean sea. .

\section{Conclusions}

1. ?Ibacus mazariorum is the only known occurrence of a fossil Ibacinid;

2. ?Ibacus mazariorum completes our knowledge about fossil Scyllaridae, a group with a particularly poor fossil record.

3. This species belongs to Ibacus Leach, 1815, or is a very closely allied species;

4. It used to live in the same biogeographic area as modern Ibacinae (Ibacus);

\section{Acknowledgements}

This study would not have been possible without the help of Claire Mellish, senior curator of the collection of graptolites and fossil arthropods at the NHMUK. I am indebted to the peoples who provided important comments that improved greatly an earlier version of my manuscript: Àlex Ossó (Tarragona) for bringing to my attention the article of Feldmann \& Schweitzer (2017); Ferran Palero (Blanes) who reminded me of the publication rejecting the monophyly of Ibacinae sensus Holhtuis (1985); and the two reviewers, Carolin Haug (Munich) and Sylvain Charbonnier (Paris) for their insightful suggestions and corrections.

\section{References}

Audo, D. \& Charbonnier, S. 2012. New Nisto of Slipper Lobster (Decapoda: Scyllaridae) from the Hadjoula Lagerstätte (Late Cretaceous, Lebanon). Journal of Crustacean Biology, 32(4), 583-590. https://dx.doi.org/10.1163/193724012X634189

Bell, T. 1858. Monograph of the fossil malacostracous crustacea of Great Britain Parts I. II. The Palæontographical society, London, 44 Pp.

Bengtson, S. 2000. Teasing fossils out of shales with cameras and computers. Palaeontologia Electronica, 3(Art. 4), 1-14.

Burkenroad, M. D. 1963. The evolution of the Eucarida, (Crustacea, Eumalacostraca), in relation to the fossil record. Tulane studies in Geology, 2(1), 2-17. 
Charbonnier, S., Audo, D., Garassino, A. \& Hyžný, M. 2017. Fossil Crustacea of Lebanon. Mémoires du Muséum, 210, 252 Pp.

Charbonnier, S., Garassino, A., Pasini, G., Métais, G., Merle, D., Bartolini, A., Brohi, I.A., Solangi, S. H., Lashari, R. A., Welcomme, J.-L. \& Marivaux, L. 2013. Early Paleogene decapod crustaceans from the Sulaiman and Kirthar Ranges, Pakistan. Annales de Paléontologie, 99, 101-117. https://dx.doi.org/10.1016/j.annpal.2012.12.003

Charbonnier, S., Garassino, A., Schweigert, G., Audo, D. \& Fernandez, S. 2014. Exceptionally preserved erymid lobsters (Crustacea, Decapoda) from the Middle Jurassic of France and Switzerland. Neues Jahrbuch für Geologie und Paläontologie Abhandlungen, 272(3), 331-339. https://dx.doi.org/10.1127/0077-7749/2014/0411

Clementz, M., Bajpai, S., Ravikant, V., Thewissen, J. G. M., Saravanan, N., Singh, I. B. \& Prasad, V. 2011. Early Eocene warming events and the timing of terrestrial faunal exchange between India and Asia. Geology, 39(1), 1518. https://dx.doi.org/10.1130/G31585.1

Clyde, W. C. Khan I. H. \& Gingerich P. D. 2003. Stratigraphic response and mammalian dispersal during initial India-Asia collision: Evidence from the Ghazij Formation, Balochistan, Pakistan. $\quad$ Geology, 10971100. https://dx.doi.org/10.1130/G19956.1

Collins, J. S. H. \& Morris, S. F. 1978. New lower Tertiary crabs from Pakistan. Palaeontology, 21(4), 957-981.

Dana, J. D. 1852. Conspectus Crustaceorum, \&c. Conspectus of the Crustacea of the Exploring Expedition under Capt. Wilkes, U.S.N. Macroura. Proceedings of the Academy of Natural Sciences of Philadelphia, 6, 10-28.

Feldmann R. M. \& Schweitzer C. E. 2017. Scyllarella (Decapoda: Achelata: Scyllaridae) from the Lookingglass Formation (Eocene): first occurrence on the western coast of North America. Bulletin of the Mizunami Fossil Museum, 43, 11-15.

Gill, T. 1898. The crustacean genus Scyllarides. Science, 7(160), 9899. https://dx.doi.org/10.1126/science.7.160.98 
Glaessner, M. F. 1965. Vorkommen fossiler Dekapoden (Crustacea) in Fish-Schiefern. Senckenbergiana Lethaea, 46a, 111-122.

Golonka, J. 2002. Plate-Tectonic maps of the Phanerozoic. Pp. 21-75 in W. Kiessling, E. Flügel \& J. Golonka (eds), Phanerozoic reef patterns, SEPM (Society for Sedimentary Geology) Special Publication, 72.

Haug, J. T., Audo, D., Charbonnier, S., Palero, F., Petit, G., Abi Saad, P. \& Haug, C. 2016. The evolution of a key chararacter, or how to evolve a slipper lobster. Arthropod Structure and Development, 45(2), 97-107. https://doi.org/10.1016/j.asd.2015.08.003

Haug, J. T., Haug, C., Waloszek, D., Maas, A., Wulf, M. \& Schweigert, G. 2009. Development in Mesozoic scyllarids and implications fort he evolution of Achelata (Reptantia, Decapoda, Crustacea). Palaeodiversity, 2, 97-110.

Haug, C., Mayer, G., Kutschera, V., Waloszek, D., Maas, A. \& Haug, J. T. 2011. Imaging and documentating gammarideans. International Journal of Zoology, 2011(380829), 19. https://dx.doi.org/10.1155/2011/380829

Holthuis, L. B. 1985. A revision of the family Scyllaridae (Crustacea Decapoda Macrura). I. Subfamily Ibacinae. Zoologische Verhandelingen, 218(1), 1-130.

Holthuis, L. B. 1991. Marine lobster of the world. FAO Fisheries Synopsis, 125(13), 1-292.

Holthuis, L. B. 2002. The Indo-Pacific scyllarine lobsters (Crustacea, Decapoda, Scyllaridae). Zoosystema, 24, 499-683.

Hu, C.-H. \& Tao, H.-J. 1996. Crustacean Fossils of Taiwan. Ta-Jen Printers Ltd., Taipei.Latreille, P. A. 1802-1805. Histoire Naturelle Générale et Particulière des Crustacés et des Insectes 3. F. Dufart, Paris, 467 Pp.

Latreille, P. A. 1825. Familles naturelles du règne animal, exposées succinctement et dans un ordre analytique, avec l'indication de leurs genres. J.-B. Baillière, Paris, 570 Pp.

Lavalli, K. L. \& Spanier, E. 2012. Infraorder Palinura Latreille, 1802. Pp. 425-532. In F. R. Schram, J. C. von Vaupel Klein, M. Charmantier-Daures \& J. Forest (eds) Treatise on Zoology - Anatomy, Taxonomy, Biology. The Crustacea. Complementary to the volumes translated from the French of the Traité de Zoologie. 9 (part A). 
Lavalli, K. L., Spanier, E. \& Grasso, F. 2007. Behavior and sensory biology of slipper lobsters. Pp. 133-181. In K. L. Lavalli \& E. Spanier (eds) The biology and fisheries of slipper lobster. CRC Press, Boca Raton. https://dx.doi.org/10.1201/9781420005165.ch7

Leach, W. E. 1815. The Zoological Miscellany being description of new, or interesting animals. McMillan, London, 154 Pp.

Lund, N. T. 1793. Slaegten Scyllarus. Iagttagelser til Insekternes Historie, 1. Skrifter Af Naturhistorie-Selskabet. Kjøbenhavn, 2(2), 17-22.

Nyborg, R. \& Garassino, A. 2017. A new genus of slipper lobster (Crustacea: Decapoda: Scyllaridae) from the Eocene of California and Oregon (USA). Neues Jahrbuch für Geologie und Paläontologie Abhandlungen, 283(3), 309316. https://doi.org/10.1127/njgpa/2017/0644

Palero, F., Clark, P. F. \& Guerao, G. 2014. Achelata. Pp. 272-278 in J. Martin, J. Olesen \& J. T. Høeg (eds) Atlas of Crustacean Larvae. Johns Hopkins University Press, Baltimore.

Palero, F., Crandall, K. A., Abelló, P., Macpherson, E. \& Pascual, M. 2009. Phylogenetic relationships between spiny, slipper and coral lobsters (Crustacea, Decapoda, Achelata). $\begin{array}{llll}\text { Molecular } \quad \text { Phylogenetics } & \text { and }\end{array}$ 162. https://dx.doi.org/10.1016/j.ympev.2008.10.003

Scholtz, G. \& Richter, S. 1995. Phylogenetic systematics of the reptantian Decapoda (Crustacea, Malacostraca). Zoological Journal of the Linnean Society, 113(3), 289328. https://dx.doi.org/10.1006/zjls.1995.0011

Smith, S. I. 1869. Description of a new genus and two new species of Scyllaridae and a new species of Ethra from North America. American Journal of Science and Arts second series, 48(142), 119-121.

Spanier, E. \& Weihs, D. 1992. Why do shovel-nosed (slipper) lobsters have "shovels”? The Lobster Newsletter, 5, 8-9.

Yang, C.-H., Bracken-Grissom, H., Kim, D., Crandall, K. A. \& Chan, T.-Y. 2012. Phylogenetic relationships, character evolution, and taxonomic implications within the 
slipper lobsters (Crustacea; Decapoda: Scyllaridae). Molecular Phylogenetics and Evolution, 62, 237-250. http://dx.doi.org/10.1016/j.ympev.2011.09.019

Yin, A. 2006. Cenozoic tectonic evolution of the Himalayan orogen as constrained by alongstrike variation of structural geometry, exhumation history, and foreland sedimentation. Earth-Science

Reviews,

76(1-2),

$1-$

131. https://dx.doi.org/10.1016/j.earscirev.2005.05.004

Zhu, B., Kidd, W. S. F., Rowley, D. B., Currie, B. S. \& Shafique, N. 2005 Age of initiation of the India-Asia collision in the east-central Himalaya. The Journal of Geology, 113, 265-285.

\section{Figures}

\section{Figure 1}

Situation of Shaisuro outcrop in Pakistan. Ghazij formation in dark grey, from Clyde et al. (2003); position of Shaisuro (circle) from Collins \& Morris (1978); faults and hinge zone from Yin (2006). Abreviations: $\mathrm{Cf}=$ Chaman fault, $\mathrm{DGK}=$ Dera Ghazi Khan, $\mathrm{Hz}=$ Hinge zone; $S=$ Shaisuro.

\section{Figure 2}

?Ibacus mazariorum nov. sp. from the Ypresian of Shaisuro. A, holotype in dorsal view, stereopair, cross-polarized light; B, interpretative line-drawing of dorsal view; C, frontal view, cross-polarized light; D, interpretative line-drawing of frontal view. Abbreviations: a= branchiocardiac groove, asmc $=$ anterior submedian carina, bc= branchial carina, $\mathrm{c}=$ postcervical groove, $\mathrm{e}_{1} \mathrm{e}=$ cervical groove, $\mathrm{ei} ?=$ cervical incision, $\mathrm{fm}=$ frontal margin, $\mathrm{ic} ?=$ intercervical carina, inc $=$ intestinal carina, $\mathrm{mc}=$ median carina, $\mathrm{o}=$ ocular incision, $\mathrm{oc}=$ orbital carina, $\mathrm{po}=$ postorbital carina, poc $=$ posterior carina. Scale bars: $10 \mathrm{~mm}$. Pictures: D. Audo, $\mathbb{C}$ NHMUK. 


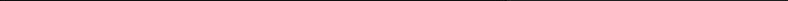



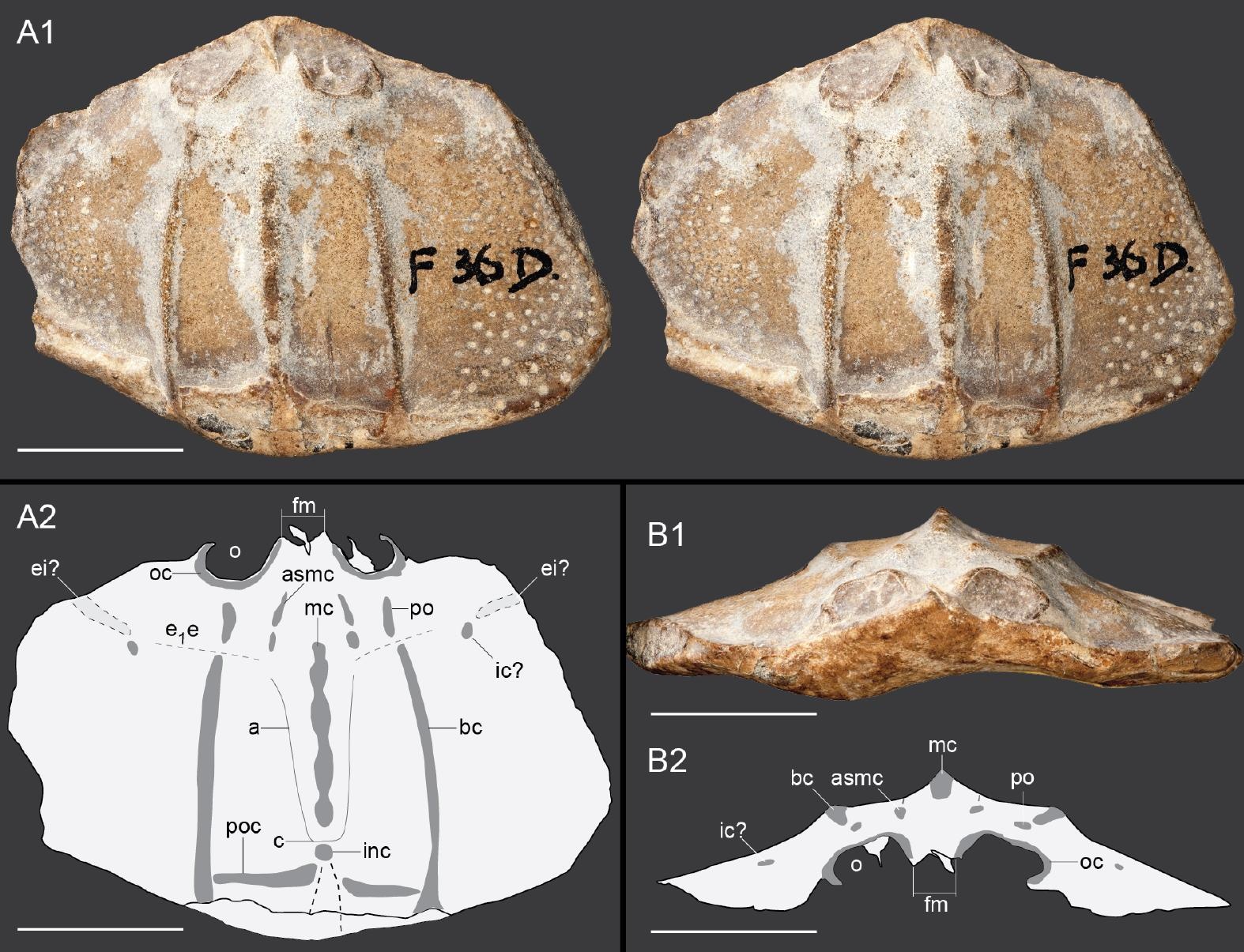


\section{Scyllaridae Latreille, 1825}

Age

\section{Sister taxa to Neoscyllarida Haug et al., 2016}

Cancrinos Münster, 1839

Cancrinos claviger Münster, 1839

Late Cretaceous (Cenomanian)

Late Cretaceous (Cenomanian)

Charbelicaris Haug et al. , 2016

Charbelicaris maronites Haug et al. , 2016

\section{Neoscyllarida $\dagger$ Haug et al. , 2016}

\section{Arctidinae $†$ Holthuis, 1985}

Acanthoscyllarides †† Audo \& Charbonnier, 2012

A. peterpani $\dagger$ † Audo \& Charbonnier, 2012 (Nisto) Scyllarides $\dagger$ Gill, 1898

S. bolcensis †† De Angeli and Garassino, 2008

S. koenigii †† (Bell, 1858)

S. punctatus †† Woods, 1925

S. tuberculatus †† (König, 1825)

\section{Ibacinae $†$ Holthuis, 1985}

Ibacus † Leach, 1815

?I. mazariorum $\dagger \dagger$ nov. sp.

\section{Scyllarinae $\dagger$ Latreille, 1825}

Biarctus † Holthuis, 2002

B. vitiensis $\uparrow$ (Dana, 1852)

Scyllarella †† Rathbun, 1935

S. aspera †† Rathbun, 1935

S. gardneri †† (Woods, 1925)

S. gibbera †† Rathbun, 1935

Scyllarus $†$ Fabricius, 1775

S. junghumi †† Böhm, 1922

S. mantelli †† Desmarest, 1822 (Nomen dubium)

\section{Unplaced at subfamily leve}

Llajassus †† Nyborg \& Garassino, 2017

L. caesius (Squires, 2000)

Palibacus †† Förster, 1984

P. praecursor (Dames, 1886)

Parsacus †† Garassino et al. , 2014

P. eocenicus Garassino et al., 2014

?P cristatus †† Förster, 1984 (Nisto)

Early Cretaceous (Albian)
Kimmeridgian-Tithonian

Bavaria, Germany

Hadjoula, Lebanon

Hadjoula, Lebanon

Hadjoula, Lebanon

Monte Postal, Italy

Sheppey Island, United Kingdom

Folkestone, United Kingdom

London Clay Formation, United Kingdom

Eocene (Ypresian)

Eocene (Ypresian)

Late Pleistocene - Recent

Paleocene

Early Cretaceous (Albian)

Paleocene

Miocene

?

Eocene (Lutetian)

Cenomanian

Eocene

Eocene

\section{Ryukyu Group, Taiwan}

Vitilevu, Fiji Island

Alabama, United States of America

Folkestone, United Kingdom

Alabama, United States of America

Java, Indonesia

United Kingdom

Llajas Formation, United States of America

Hakel and Hadjoula, Lebanon

Baba-Heydar, Shar-e-Kurd area, Iran Bolca, Italy
Haug et al. (2009)

Haug et al. (2016)

Haug et al. (2016)

Audo \& Charbonnier (2012)

De Angeli \& Garassino (2008) Förster (1984)

Förster (1984)

Quayle (1987)

This study

Förster (1984)

Förster (1984)

Förster (1984)

Förster (1984)

Förster (1984)

Desmarest (1822)

Nyborg \& Garassino (2017)

Förster (1984)

Garassino et al. (2014)

Haug \& Rudolf (2015) 


\section{Previously assigned to Ibacinae}

Parribacus † Dana, 1852

P. japonicus † Holthuis, 1960

Neogene (Pleistocene) - Recent

Oligocene
Ryukyu Group, Taiwan

Bad Iwonicz, Poland
Hu and Tao (1996)

Glaessner (1965) 


\section{Supplementary material}

\section{Table 1}

Table 1: List of fossil slipper lobsters (Decapoda: Scyllaridae). Only postlarvae (nisto) and adults are included. Scyllaridae undoubtedly also occur in the fossil record as larvae. These larvae, the phyllosoma stages (Palero et al. 2014), are even more common than adults (Carolin Haug pers. comm. 2017). Unfortunately, the phyllosoma stages have a common morphology in all Achelata Scholtz \& Richter, 1995. So it is often difficult, especially on fossil, to know if they correspond to Scyllaridae or to the more abundant Palinuridae Latreille, 1802. Note that Scyllarella manleyi Feldmann \& Schweitzer, 2017 does not appear in this list because it is herein considered as a more recent synonym of Llajassus caesis (Squires, 2001). Indeed, S. manleyi holotype corresponds to a specimen which was convincingly ascribed to Llajassus caesius by Nyborg \& Garassino (2017).

\section{Additional references for supplementary material}

Böhm, J. 1922. Arthropoda. Crustacea. Pp. 521-535, pl. 63 in K. Martin (ed.), Die Fossilien von Java. Sammlungen des Geologischen Reichsmuseums in Leiden, (neue Folge), 1(2). E. J. Brill, Beiden.

Dames, W. Ueber einige Crustaceen aus den Kreideablagerungen des Libanon. Zeitschrift der Deutschen Geologischen Gesellschaft 38, 551-575.

De Angeli, A. \& Garassino, A. 2008. Pseudosquilla lessinea n. sp. (Crustacea, Stomatopoda, Pseudosquillidae) and Scyllarides bolcensis n. sp. (Crustacea, Decapoda, Scyllaridae) from the lower Eocene (Ypresian) of Monte Postale (Altissimo, Vicenza, NE Italy). Atti della Società italiana di Scienze Naturali e del Museo Civico di Storia Naturale in Milano, 149(2), 167-178.

Desmarest, A.-G. 1822. Les crustacés proprement dits. Pp. 67-142, pls. 5-11 in A. Brongniart \& A.-G. Desmarest (eds.), Histoire naturelle des crustacés fossiles sous les rapports zoologiques et géologiques. F.-G. Levrault, Paris. 
Fabricius, J. C. 1775. Systema Entomologiae, sistens Insectorum classes, ordines, genera, species, adiectis synonymis, locis, descriptionibus, observationibus. Officina Libraria Kortii, Flensburg and Leipzig.

Förster, R. 1984. Bärenkrebse (Crustacea, Decapoda) aus dem Cenoman des Libanon und dem Eozän Italiens. Mitteilungen der Bayerischen Staatssammlung für Paläontologie und historische Geologie, 24, 57-66.

Garassino, A., Bahrami, A., Yazdi, M. \& Vega, F. J. 2014. Report on decapod crustaceans from the Eocene of Zagros Basin, Iran. Neues Jahrbuch für Geologie und Paläontologie Abhandlungen, 274(1), 43-54. https://dx.doi.org/10.1127/njgpa/2014/0442

Garassino, A. \& Schweigert, G. 2006. Cretasergestes sahelalmae n. gen., n. sp. (Crustacea, Decapoda, Sergestoidea) and Cancrinos libanensis n. sp. (Crustacea, Decapoda, Palinuroidea) from the Upper Cretaceous (Cenomanian) of Lebanon. Atti della Società italiana di Scienze naturali e del Museo civico di Storia naturale in Milano, 147, 69-78.

Haug, J. T. \& Rudolf, N. R. 2015. A nisto larva of an Eocene slipper lobster (Neoscyllarida). Palaeodiversity, 8, 113-119.

Holthuis, L. B. 1960. Preliminary descriptions of one new genus, twelve new species and three new subspecies of scyllarid lobsters (Crustacea Decapoda Macrura). Proceedings of the Biological Society of Washington, 73, 147-154.

König, C. D. E. 1825. Icones fossilium sectiles. G. B. Sowerby, London.

Münster, G. Graf zu 1839. Decapoda Macroura. Abbildung und Beschreibung der fossilen langschwänzigen Krebse in den Kalkschiefern von Bayern. Beiträge zur PetrefaktenKunde, 2, 1-88.

Quayle, W.J. 1987. English Eocene Crustacea (Lobsters and Stomatopods). Palaeontology, 30(3), 581-612, pls 64-67.

Rathbun, M. J. 1935. Fossil Crustacea of the Atlantic and Gulf Coastal Plain. Special Papers of the Geological Society of America, 2(8), 1-160.

Squires, R. L. 2001. Additions to the Eocene megafossil fauna of the Llajas Formation, Simi Valley, southern California. Contributions in Science, 489, 1-40. 
Woods, H. 1925-1931. A monograph of the fossil macrurous crustacean of England. The Palæontographical Society, London. 